\title{
Art as a Result of the Highest Achievements of Genius
}

\author{
Maria Matyushova \\ Peoples' Friendship University of Russia \\ 6 Miklukho-Maklaya Str. \\ Moscow, Russia \\ E-mail: maria_matushova@mail.ru
}

\begin{abstract}
All art can be considered as a result of higher achievements in the work of geniuses. This paper considers the development of representations about talent and the genius in the history of esthetics. The author shows how the ancient image of the inspired poet anticipates later notions of genius, developed into the $18^{\text {th }}$ and the $19^{\text {th }}$ century. Geniuses were perceived as mediums, mediators between gods and people. The article also touches on the problem of the correlation between genius and sickness, which was reflected in many works of Russian psychiatrists of the early 20th century. In conclusion the author tries to give analyze different views on the nature of genius and to reveal the most typical lines of the ingenious person.
\end{abstract}

Keywords-creativity; talent; genius; inspiration; illness; pathography; europathology; ingeniology

\section{INTRODUCTION}

All art can be considered as a result of higher achievements in the work of geniuses. The history of literature, painting, music is not only the history of this or that art, but also the history of the highest bright pick of spiritual activity of humankind. The central concept of aesthetics and the philosophy of art is the "genius" and if you ignore this aesthetic category, and with it the historically established content, then the artist's activity loses its meaning. If there is no "good" and "bad" in the result of creativity, then creativity loses its meaning.

Over many centuries, the problem of the true nature of talent and genius attracted researchers to its mystery. Many great minds have tried to solve this problem. Only the 20th century 'expelled' this category from philosophy and aesthetics, replacing it with the concept of the author, until Roland Bart came to the conclusion of the "death of the author".

More recently, however, we have a new tendency in American psychology that says that all people are genius persons in one way or another and society has to create the right conditions for the development of this ability.

Who is in the right? What are the views on the nature of talent and genius throughout the history of culture? In addition, can we identify a certain formula of genius and identify strong points of genius?

\section{DEFINITIONS OF GENIUS: FROM ANTIQUITY TO THE EARLY MODERN PERIOD}

The problem of creativity, as a transition from non-being to being, as well as talent and genius in art as the main and indispensable condition of creative activity, arose in ancient Greece, and it was there that the concept of "genius", denoted a demonic being, "inner voice" Socrates, which he heard from childhood.

Later, Plato developed the idea that geniuses are original intermediaries between gods and people, and their task is to transmit to the gods prayers and victims from people. And then only thanks to geniuses: "... the universe is connected by inner connection ... Without touching people, the gods communicate and talk with them only through the geniuses both in reality and in a dream" [1].

Plato's views on the nature of art and talent coincided with the traditional understanding of art in antiquity, considering all creative activities of man as primarily driven by the knowledge of the rules of the respective activities.

However, it was Plato who drew attention to the specifics of poetic creativity. For Plato, the gift of the poet is a sacred gift, a divine frenzy. A true poet, Plato believes, does not owe anything to himself, or mastery: his visions are a gift from above, as well as the revelations of the Delphic prophetess or sacred sibyl.

This point of view is shared by Aristotle, although Aristotle least of all speaks of the unusual nature of poetic creativity.

Throughout the Middle Ages, when speaking of creativity, people mostly referred to the creativity of God. God appears as the Great Artist, the Architect who creates the world as a huge work of art according to a thoughtthrough plan. The role of the artist was to reflect the integrity, beauty and order of the divine universe. In this sense, the artist's work is always secondary, for the artist constantly turns to God. In general, of course, the creativity of the Artist, according to the bright remark of the famous French medievalist J. Duby "was a victim, an offering. It has more magic than aesthetics" [2]. 
In the Renaissance, the situation changes, and this is primarily due to a change in the artist's social status: he gradually turns from an artisan into a free artist. It will be a long process of separating art from craft, and professionalization of artistic activity will become more profound. This will happen due to the transition from direct order to work on the market.

Representations about the artist in this period are filled with new content, for the Renaissance highlights the idea of a comprehensive, universal development of the artist's personality. In addition, it is a person who, by his own laws, sets his own rules in art. The artist himself and the poet are increasingly compared with a philosopher, with a sage capable of expressing the wisdom of the world.

At the same time, representatives of the Renaissance had a clear understanding that no knowledge could replace what was called "natural inclination". What did they mean by this? For Durer it is, first of all "a rich imagination, full of images, fecundity so rich and original that if he lived for hundreds of years, then he could every day create figures that no one had ever seen before" [3].

In the Age of Enlightenment, the development of the concept of "genius" is further progressed. J.B. Dybos, in his famous work Critical Reflections on Poetry and Painting, considers the problem of genius multilaterally. It is difficult to find in the history of aesthetics another representative who devoted so many pages to the definition of a genius, its characteristics and, what determines the success and failure of his creations. Genius, in the opinion of Dubois, is primarily predetermined by natural bases, which are associated with the presence of an exceptional anatomical and physiological organization of the organism.

In addition, the main property that determines all other qualities of genius, J.B. Dubos sees in sensitivity, which is much stronger in his degree of expression and manifestation than in ordinary people. The idea that the genius is based on «extreme sensitivity» found followers, both in France and in Germany. Later, Diderot writes about the genius as follows: "His beginning is an extreme sensitivity, making him receptive to a multitude of impressions" [4].

Acute sensitivity, according to J.B. Dubos, should be supplemented by imagination, or as he calls, "creative imagination". It is also an innate quality; gifted people possess it, both in the field of art, and in rhetoric. In all these spheres of human activity, the imagination, often identified as intuitive foresight, dominates over the accumulated knowledge, acquired experience. This is what distinguishes genius in the area of arts from genius in the natural sciences, in which it is impossible to create anything new without mastering the existing. In the field of art and rhetoric: "A genius can create art himself and choose a method for him" [5].

This very deep thought of J.B. Dubos precedes Kant's statement that genius gives rules to art. Indeed, if in the natural sciences the progress is realized thanks to the direct mastery of the existing knowledge, which creates the prerequisites for discoveries in science, then in arts it is more complicated. The specificity of scientific knowledge is manifested in the collective experience of mankind, which is absolute in character. Progress in the natural sciences is a progressive development, where the emergence of subsequent links is based on existing knowledge. Art also represents the collective experience of humankind, but the existing experience no longer has such direct, directly deterministic influence.

Considering the process of creating a genius of a work of art, the French educator pays special attention to the problem of inspiration. The mystery of this process, as we have already seen, has generated a lot of interpretations and misunderstandings.

Describing the state of inspiration, J.B Dubos highlights some of the features inherent in this process. First of all, the arrival of inspiration is noted in the poet's state of selfoblivion. At this moment, the genius creates unconsciously images, which he supposedly did not think of. This happens intuitively and is done in a state of "intoxication", even frenzy.

The author of the treatise states that the state of inspiration is the highest stage of the creative process, preceded by a long, laborious work on the plot and the plan of the work. When inspiration came to a genius, he creates easily, all difficulties recede, ideas are easily expressed. However, what is created in a fit of inspiration should be "polished".

Dubos also emphasizes that an artist has to know life, because only a real experience is the source of great ideas. In addition, the disclosure of genius prerequisites requires certain social conditions, and above all, the state's interest in the development of art and an encouraging its creators.

The classical division of the concepts "Genius" and "Talent" was given by I. Kant in his work Criticism of Judgment. Kant sharply differentiates between art and science, which can be defined by known rules. A characteristic feature of the Artist, in contrast to the Scientist, Kant considered the natural gift of the first. This is the ability to create something that cannot be determined by any rules: "genius is a talent (gift of nature), which gives art rules. Since talent, as the inherent productive capacity of the artist, belongs to nature itself, one can express this thought and thus: genius is the innate ability of the soul (ingenium), through which nature gives art rule" [6].

In this case, Kant is right in that the nature of art, in contrast to science, uses the language of images, which can't be translated completely into the language of science. The language of concepts can't adequately explain the content of music, poetry, and painting.

Kant also believed that the most important ability of the genius is taste. Taste plays the role of limiting the arbitrariness of genius, as taste "cuts the wings of genius". It is the taste compels the artist long and painfully looks for the perfect form of expression for the aesthetic idea that came to him at the moment of inspiration. 
In the future, Romanticism put forward the cult of Genius as a spiritual prophet: genius was not understood as a specific ability, which possesses a creative person, but as a kind of mystical power that grasps it. Romantics are convinced that fantasy, imagination, insight, intuition, rather than rational thinking, are more important in artistic creation.

G.F. Hegel, in his Lectures on Aesthetics, devotes a whole section to the problem of talent and genius, which he calls "The Artist". Unlike Kant, Hegel, defining the concept of "Genius", asserts that: "The word Genius is a completely general designation, used not only in relation to artists, but also in relation to the great generals and kings, as well as the heroes of science" [7]. Therefore, talent is a certain predisposition to one or another type of activity, the first step to the universality of the genius

Hegel calls a naturally given fantasy as the outstanding artistic ability to express a figurative reality. At the same time, the German thinker distinguishes fantasy from imagination, because in his opinion, it is creative in contrast to the passive imagination.

At the same time, the Artist, before creating a work, must, according to Hegel, see a lot, hear a lot and save much in his memory. In addition, he must know and understand the inner world of man with his soulful passions and goals. All this must go through the artist's own world; he must have a lot of experience before he can translate the true depths of life into concrete images. That is why although genius flares up in youth, as was the case with Goethe and Schiller; only mature aged and experienced artists are capable of producing a completed, genuinely mature works of art.

At the end of the $19^{\text {th }}$ century, A. Schopenhauer quite thoroughly expounded his conception of the nature of genius and art, a concept that will later contribute to the emergence of the ideas of A. Bergson, Freud's existentialists.

A. Schopenhauer considered art as the highest form of knowledge that has the power to reveal the essence of the world much deeper than all the sciences combined. A genius in art is a great artist, a great philosopher with intuition, and he sees the essence of the phenomenon with greater clarity than others do.

Genius people differ from other people through anatomical signs and physiological processes, nervous system, heightened sensitivity, irritability, melancholy, childish spontaneity, and a playful attitude to the world. In this sense, natural traits of a genius always have more significance than education and the social environment that surrounds him.

Talents are always imbued with the spirit and needs of their time, they undoubtedly benefit society, find recognition among contemporaries, gain "approval of the crowd" and receive material benefits (Schopenhauer recalls that the word talent originally meant money). A genius always rises above the crowd and talent in art, as his creations are not objects of profit, and while every interest indicates dependence, a genius is independent. The sole purpose of his creativity is creativity itself. Because of this, the genius very rarely finds recognition in life, as a rule, it is discovered by distant descendants, after his death, after "how the generation, among whom and for whom he wrote first, will die out" [8]. Geniuses stretch out their hands through the centuries.

The most distinctive feature of a genius is his antisociality, loneliness and the fact that his contemporaries' lack understanding of his creativity, which he creates for humanity. Schopenhauer said geniuses live more for others than for themselves. The tragedy of a genius lies in the fact that he, feeling his greatness and superiority, "is condemned to live in an empty world, not meeting himself like on an island not inhabited by anyone except monkeys and parrots ... To be great and forced to live among a miserable rabble - it's synonymous" [9].

Many philosophical and aesthetic ideas of Schopenhauer were perceived and developed by F. Nietzsche. Nietzsche opposed an ordinary man, this herd animal to the ideal of the Superman.

\section{GENIUS AND ILLNESS}

The interest of philosophers in the unconscious nature of creativity contributed to the fact that doctors became interested in this problem, and at the end of the nineteenth century the idea of a genius as the highest stage of human development and as a man of the future gradually moved from the field of philosophy and aesthetics to medicine and psychiatry.

The classic work on the relationship between genius and sickness and insanity is the work of the Italian anthropologist and criminalist C. Lombroso, who in his famous book «Genius and Insanity», quoting Plato, Aristotle, Democritus, draws a parallel between insanity and inspiration, and insanity and the prophecy. C. Lombroso repeats the thoughts that were expressed long before him, that genius primarily is a subtle and almost painful sensitivity, a characteristic that, for a genius person is the source of his suffering and glory. According to him, excessive vanity distinguishes a genius personality of other people. In addition, the genius is characterized as having a very gloomy view of the world and as a person, who is full of melancholy, possibly with a depression: "Melancholy, despondency, shyness, selfishness - that's a brutal retribution for higher mental talents" [10].

Many psychologists, art critics, artists and representatives of various fields opposed against the point of view of Lombroso, directly linking genius and illness, poetry and insanity. Even the Freudians, to whom Lombroso tried to join, did not accept his ideas, believing that he was vulgarizing Freud's views on the nature of talent.

Despite the existence of many similarities between geniuses and lunatics, Lombroso contradicts himself by deducting the proposition that "everything must necessarily be insane". He tries to be objective, speaking of willpower and a sound mind of artists such as Dante, Michelangelo, Galileo, Kepler, Voltaire, and others.

There were studies that began to see "deviation from the norm" in genius finding them either in the structure of the brain, or in heredity. 
One of the first to engage in these studies was the German neurologist and psychiatrist Paul Josef Moebius (1853-1907), who introduced the use of the term "pathography" into science. Pathological studies involve studying the activities of an outstanding personality, by supplementing the biography of a genius personality with information about his illness - a pathological manifestation of personality. Moreover, it was in pathological studies in those the analysis of a connection between illness and creativity began. One of those studies for example was the work of K. Jaspers, written in 1925, Strindberg and Van Gogh, in which Jaspers argued that Strindberg, like Hölderlin, Van Gogh were mentally ill, and that this illness was the decisive factor for the formation of their worldview (the first chapter is called Strindberg's Pathography).

In Russia, Professor Chizz (1855-1922), who headed the Department of Psychiatry at the University of Yuryev (Tartu) draws a direct link between genius and illness. His works include Turgenev as a Psychopathologist, Dostoevsky as a Criminologist, and in 1904 he published a major work $N$. Gogol.

It is also necessary to name Professor Bazhenov (18571923), chairman of the board of the Russian Union of Psychiatrists and Neuropathologists, who was one of the first to formulate the idea that genius is the prototype of a man of the future. It was him who proposed to call the development of humanity to the stage of genius 'progeneration'. Bazhenov assumed that the mental disorders of a genius are a «byproduct» of his powerful spiritual activity.

In his book Psychiatric Talks on Literary and Social Topics Bazhenov writes about mentally ill writers: E. Po, Dostoevsky, and Maupassant. In addition, he describes the work of famous symbolists and decadents, such as Bryusov, Baudelaire, Verlaine, and others, also diagnosing them as mentally ill.

Undoubtedly, during this period, the most significant were the works of Professor Gruzenberg, who tried to penetrate the essence of the creative process. In his twovolume book: The Psychology of Creativity and Genius and Creativity he analyzed the mechanisms of the creative process, linking it with pathological states.

The professor of the Ural University, Segalin contributed significantly to the study of the genius and proposed the foundation of the Institute of Genius Creativity in 1920. Later, from 1925 to 1930, he published the journal Clinical Archive of Genius and Giftedness. Segalin assumed that the creation of the Institute of Genius Creativity would lead to the emergence of a new science of "Ingeniology" that is, the science of a genius man. He also introduced the term "Europathology", which denoted pathology, which in one way or another is related with a creative personality.

Further to the solution of this problem tried to contribute researchers from the field of psychoanalysis, the founder of which was Sigmund Freud. Arguments on the problems of art and creativity are contained in works such as Freud's Lectures on the Introduction of Psychoanalysis, Dissatisfaction with Culture; furthermore, these questions are in focus of the following essays: Leonardo da Vinci. Etude of Psychosexuality, Dostoevsky And Parricide, Poet and Fantasy and Wit and Its Relation to The Unconscious.

The study by Freud of various problems of art is associated with his theory of the unconscious. "Understanding of unconscious mental activity» wrote Freud, «made it possible for the first time to get an idea of the essence and creative activity of the poet" [11].

Thus, psychoanalysis, which regards the spiritual life of man as a complex interaction of conscious and unconscious processes, tried to disclose the contradictoriness and ambiguity of the Artist's inner world. This led to the identification of artistic creativity with psychic therapy, and artists - with people on the verge of insanity. Freud's thesis was developed into a view, according to which the artist is a neurotic, struggling with his insanity through the creation of artistic images.

The psychoanalytic explanation of the artist and his creative process by Freud had a tremendous impact on art history and the development of art in the twentieth century. It is difficult to understand the trends in art such as surrealism, dramatic cruelty, the theater of the absurd, the poetry of detachment, including the literature of the "stream of consciousness" without an analysis of the basic principles of Freudianism in the field of artistic creativity,

\section{CONCLUSION}

By looking at all the above-mentioned points of view, we summarize the most characteristic features of a genius personality.

First, it is an innate ability to a certain kind of creativity, based on biological, anatomical and physiological prerequisites. The whole experience of the history of art shows that this ability can be developed or, on the contrary, lost, but cannot be acquired; it was programmed in the personality genotype.

Sharp impressionability and acute observation - that are key traits of Rousseau, Balzac, Tolstoy, and Dostoevsky as we describe the inner world of those men and their experiences.

The intuitive vision of the essence of phenomena. A genius is always the discoverer, the inventor, he has an intuitive vision of the essence of phenomena, and he sees the distant light of a lighthouse, which no one else sees. He opens new ideas to the world, be it science, arts or religion. He does not recognize established rules or principles, but he himself creates rules and laws; he, admitting authority and leadership, at the first stage never follows the old beaten path, but chooses a new, sometimes stony, and not very convenient to go further. This causes discontent on the part of public opinion, but he fearlessly goes further and at the end of the path can get recognition of his merits.

Memory, which preserves the insights of an artist's observations in his mind and allows him to remind them for whole compositions and storylines. For example, Flaubert claims that he remembered himself from two and a half years; 
Dostoevsky reported that his hero Alyosha remembered his late mother from the age of four. We know about Pascal's extraordinary memory - there is information that he could memorize the Bible by heart.

Creative imagination, the mental transformation of the accumulated real life and the transfer of ideas from reality into artistic images.

The artist's ability to inspire, including a creative upsurge and a special tension of all spiritual and physical powers that forms the condition for the productive activity of the imagination and the practical embodiment of its results.

High skill, which is manifested in the ability to find the appropriate form for content, based on hard work, the knowledge of life and the ability to embody that in a work, as well as the ability to reflect not only the problems of his time, but of eternal, lasting significance in his work.

Strong will, purposefulness, faith in one's destiny, allowing to overcome all obstacles on the way to creating a masterpiece.

However, listing all these qualities, can we say that we have discovered the secret of creativity and that the combination of these qualities will give us a genius personality? The author does not think so, because the issue is still subject of heated discussions. And this is understandable, because the penetration into the nature of giftedness to an extent that it gives an opportunity to gain direct control of it and the ability to manage it, would apparently also lead to the destruction of it.

\section{REFERENCES}

[1] Plato, Feast (202e) in the book // Platon.Fedon, Feast, Phaedrus, Parmenides //. M., 1990, p.112

[2] J.B. Dubos, The time of the cathedrals. M., 2002, p. 39.

[3] A. Durer, Diaries, letters, treatises. M., 1987. Vol.2, p. 45.

[4] D. Diderot, Genius. / Aesthetics and Literary Criticism. M., 1980, p. 211.

[5] J.B. Dubos, Critical reflections on poetry and on painting. M., p. 543.

[6] I. Kant, Criticism of Judgment. M., 1994, p. 180.

[7] G.F. Gegel, Aesthetics .T.1 M.,1968, p .291.

[8] A. Schopenhauer, New Paralipomena. // Interesting. M., 1997, p. 322.

[9] Ibid., p.152.

[10] C. Lombroso, The genius and insanity. A parallel between great people and crazy people. $\mathrm{SPb}$.: 1892, p. 24.

[11] Z. Freud, Lectures on the Introduction to Psychoanalysis, T.2.M., 1922, p. 165. 